\title{
BALANCED SCORECARD UNTUK MENILAI KINERJA PERUSAHAAN (BARAYA TRAVEL BANDUNG)
}

\author{
Delly Sukmanawan \\ del_inside@yahoo.com \\ Azhar Affandi \\ Universitas Pasundan
}

diterima: 2/2/2019; direvisi: 4/7/2019; diterbitkan: 31/8/2019

\begin{abstract}
Uncertainty in an increasingly competitive business environment, especially in the raising and emergence of several new companies in travel transportation services, should encourage a company to be able to have better performance to compete. Companies are faced with various threats and opportunities that emerge in the business environment, thus exposed to the uniformity of the company's performance measurement tools as an instrument of the company's performance evaluation. Measurement of company performance applied by Baraya Travel Bandung still use traditional performance measurement, incomprehensive and not optimal yet. Baraya Travel Bandung needs a performance measurement tool that can provide an overview of the overall achievement of the company's business. The design of performance measurement tool that became the purpose of this research is Balanced Scorecard. The design of performance measuring tools using the Balanced Scorecard begins with translating the company's vision, mission and strategic objectives that are linked into four perspectives in the Balanced Scorecard.
\end{abstract}

Keywords: balanced scorecard; four perspectives; optimum performance measurement

\begin{abstract}
Abstrak
Ketidakpastian dalam lingkungan bisnis yang semakin kompetitif dengan munculnya beberapa perusahaan baru pada bidang jasa transportasi travel membuat perusahaan harus mampu memiliki kinerja yang lebih baik untuk dapat bersaing. Perusahaan dihadapkan pada berbagai ancaman dan peluang yang muncul di lingkungan bisnis, sehingga dihadapkan pada keselerasan alat ukur kinerja sebagai instrumen dari evaluasi kinerja perusahaan. Pengukuran kinerja perusahaan yang diterapkan oleh Baraya Travel Bandung masih menggunakan pengukuran kinerja tradisional, belum komperhensif, serta belum dapat dikatakan optimal. Braya Travel Bandung membutuhkan alat ukur kinerja yang mampu memberikan gambaran terhadap keseluruhan pencapaian bisnis perusahaan. Sehingga rancangan alat ukur kinerja yang menjadi tujuan dari penelitian ini adalah Balanced Scorecard. Perancangan alat ukur kinerja dengan menggunakan Balanced Scorecard diawali dengan menterjemahkan visi, misi dan sasaran-sasaran strategis perusahaan yang dihubungkan kedalam empat perspektif yang ada dalam Balanced Scorecard.
\end{abstract}

Kata Kunci: balanced scorecard; empat perspektif; pengukuran kinerja optimal 


\section{PENDAHULUAN}

Pembenahan dan pembangunan pada sektor transportasi publik gencar dilakukan oleh pemerintah serta diikuti pula dengan pembangunan infrastruktur penunjang transportasi publik seperti perluasan jalan tol yang menghubungkan antar kota. Pembangunan dan perbaikan infrastruktur pada sektor transportasi publik berimbas pada para pelaku bisnis yang bergerak di bidang transportasi. Mudahnya akses yang menghubungkan antar kota dan meningkatnya minat masyarakat terhadap transportasi publik dipandang sebagai peluang bagi para pelaku bisnis dalam bidang transportasi, di sisi lain pembangunan pada sektor transportasi publik berdampak pada persaingan bisnis transportasi yang semakin kompetitif. Transportasi darat hingga saat ini merupakan transportasi yang sangat diminati oleh sebagian besar pengguna alat transportasi. Pembangunan Tol Cipularang yang menghubungkan berbagai daerah yang ada di sekitar Bandung, membuat akses darat dari Bandung ke Jakarta ataupun sebaliknya menjadi semakin mudah dan cepat. Perkembangan perusahaan jasa travel Bandung-Jakarta sampai saat ini masih berkembang dengan pesat dengan banyaknya perusahaan travel baru yang hadir. Chief Business Development PT Cipaganti Citra Graha, Wahyudi Parulin yang mengatakan bahwa pertumbuhan bisnis travel mencapai 10\% hingga 20\% setiap tahunnya (www. pikiran-rakyat.com/ekonomi/2013/05/02/233418/ pertumbuhan-bisnis-travel-capai-20-persen-tahun diakses pada 9 Juni 2017 Pukul 14.56).

Berdasarkan rekomendasi yang diajukan oleh perusahaan travel pada Dinas Perhubungan Kota Bandung hingga Agustus 2017, terdapat 18 perusahaan travel yang ada di Bandung. Berdasarkan observasi peneliti, terdapat 2 travel baru yang memiliki trayek Bandung - Jakarta, yaitu MyTrans dan Sahabat Shuttle. Hingga tahun 2017 ini pemerintah sedang membangun konstruksi kereta cepat tujuan Bandung - Jakarta, hal ini membuat transportasi darat tujuan Bandung Jakarta semakin beragam. Berbagai moda transportasi darat Bandung - Jakarta yang bermunculan, membuat persaingan bisnis di bidang travel semakin kompetitif dan ancaman datang terhadap moda transportasi lainnya, untuk kelangsungan hidup jangka panjang perusahaan harus terus melakukan evaluasi kinerja guna menunjang kelangsungan bisnisnya dimasa depan.

Baraya Travel merupakan salah satu travel populer yang memiliki trayek Bandung - Jakarta. Berdasarkan hasil observasi dan wawancara kepada sepuluh responden yang merupakan pelanggan Baraya Travel, peneliti memperoleh temuan berupa $60 \%$ pelanggan mengatakan bahwa perlu perbaikan dan peningkatan pada pelayanan dan armada yang dipergunakan, 30\% mengatakan cukup puas dan $10 \%$ mengatakan tidak puas. Berdasarkan hasil analisis SWOT yang dilakukan oleh peneliti, Baraya Travel berada pada posisi ST
(Strength - Threats), dimana perusahaan berada pada posisi memiliki kekuatan namun menghadapi ancaman yang membuat perusahaan harus selalu memiliki kinerja yang lebih baik agar dapat mengatasi berbagai ancaman yang datang. Dalam melakukan pengukuran kinerja perusahaan, Baraya Travel masih menggunakan pengukuran kinerja tradisional dengan hanya mengukur aspek kondisi outlets, kerapihan dan kebersihan karyawan, armada serta pelayanan. Baraya Travel belum memiliki pengukuran kinerja yang komperhensif, koheren dan seimbang yang dapat mengukur kinerja perusahaan berdasarkan visi dan misi perusahaan.

Visi Baraya Travel adalah menjadikan perusahaan transportasi yang terbaik di kelas jasa angkutan travel, cargo, dan tours \& travel. Misi Baraya Travel adalah memberikan pelayanan yang terbaik untuk semua pelanggan, mengedepankan pelayanan jasa transportasi travel dan kargo, dan memberikan pelayanan yang terbaik kepada pelanggan dan turis dalam serta luar negeri, memberikan harga yang terbaik untuk jasa transportasi, kargo dan pelayanan wisata dalam dan luar negeri serta memberikan solusi perjalanan wisata terbaik untuk pelanggan.

Balanced Scorecard (BSC) memiliki empat perspektif yang meliputi keuangan, pelanggan, proses bisnis internal, serta pembelajaran dan pertumbuhan (Kaplan, 2010). Kairu, et. al. (2013) menyatakan BSC dapat memberikan manajer perusahaan dan organisasi manfaat untuk menilai kinerjanya secara akurat dan menempatkannya pada posisi persaingan yang lebih baik. BSC merupakan konsep pengendalian strategik yang mengukur kinerja keuangan dan non-keuangan serta mempertimbangkan faktor internal dan eksternal yang mempengaruhi strategi bisnis (Zizlavsky, 2014). BSC sebagai alat manajemen stratejik memungkinkan untuk menjelaskan dan menterjemahkan misi dan strategi organisasi, memungkinkan proses komunikasi, kesesuaian strategi dan pembelajaran organisasi (Quesado, et. al. 2017). BSC dapat digunakan untuk memperoleh nilai, mengendalikan kompetensi inti, memberikan kepuasan bagi pelanggan dan menawarkan bonus bagi pemegang saham (Divandari and Yousefi, 2011). BSC dapat mendorong kinerja karyawan, dengan menyelaraskan tujuan individu dengan perusahaan (Alao, 2013). Namun demikian BSC dianggap asing bagi perusahaan yang belum menerapkannya secara menyeluruh (Malgwi, A. A \& Dahiru, H., 2014).

Organisasi di India telah menggunakan seluruh dimensi BSC sebagai alat pengukur kinerja dan menggunakannya untuk menciptakan perubahan dan meningkatkan kinerja (Farooq and Hussain, 2011). Di Australia Barat, kebijakan penerapan BSC secara hukum diwajibkan oleh pemerintah, berdampak pada struktur organisasi, operasi dan kinerja secara menyeluruh (Ridwan, et. al. 2013). Manajemen kinerja 
strategi dan konsep keberlanjutan perusahaan secara bertahap menjadi pusat perhatian bagi perusahaan di Slowakia (Rastivlav \& Petra, 2016). Manajer keuangan perusahaan yang terdaftar di Palestine Exchange menggunakan perspektif keuangan dan pelanggan dalam penilaian kinerja (Saad \& Daraghma, 2016). Di lain pihak Awadallah and Allam (2015) mengemukakan bahwa perspektif BSC tidak mempertimbangkan perspektif yang kelima, yaitu kepuasan, kontribusi, strategi, proses dan kemampuan stakeholder menjadi prisma kinerja (the performance prism).

Evaluasi kinerja secara komperhensif dan tepat dapat membantu perusahaan untuk mengetahui capaian kinerja atas aktivitas bisnis serta menunjang kinerja di masa datang dalam pengelolaan sumber daya secara optimal. Baraya Travel memiliki visi dan misi yang menggambarkan cita-cita dan tujuan sebagai tolok ukur pencapaian kinerja serta merupakan awal dari perancangan sistem pengukuran kinerja berbasis BSC (Fill, et. al., 2015 ; Brillianty \& Bendatu, 2013; Maslihatin, 2016). BSC memiliki tema strategis serta tema dan kelompok pengukuran yang berbeda dan sasaran strategis perusahaan dikaitkan dengan tema dan kelompok pengukuran dalam perspektif BSC (Senvar, et. al., 2014 ; Lin, et. al.,2014). Lead Indicator dan Lag Indicator merupakan indikator yang saling berkaitan serta dapat digunakan sebagai indikator kunci dalam melakukan penilaian kinerja perusahaan, hal tersebut senada dengan (Reefke \& Trocchi, 2013 ; Brillianty \& Bendatu, 2013 ; Maslihatin, 2016).

Tujuan penelitian ini adalah untuk mengidentifikasi model pengukuran kinerja yang digunakan, menganalisis capaian kinerja perusahaan, memahami hambatan pengukuran kinerja serta merancang model pengukuran kinerja berbasis BSC sebagai usulan bagi Baraya Travel Bandung. Bagan kerangka pemikiran ditunjukkan pada Gambar 1.

\section{METODE}

Metode yang digunakan adalah penelitian kualitatif dengan pendekatan studi kasus, di mana peneliti berusaha merancang penilaian kinerja pada Baraya Travel Bandung dengan menggunakan pendekatan BSC. Data yang digunakan diperoleh dari sumber data primer dan sekunder. Peneliti melakukan wawancara dengan beberapa narasumber seperti supervisor Baraya Travel Bandung yang merupakan pimpinan dari Baraya Travel cabang Bandung.

Observasi dilakukan dengan mengamati objek penelitian berdasarkan beberapa outlet Baraya Travel yang berada di Bandung, sehingga pengamatan dilakukan secara menyeluruh. Data yang dapat dikumpulkan dengan dokumentasi adalah data berupa format sistem pengukuran kinerja yang digunakan oleh Baraya Travel Bandung, serta objek dan kondisi outlet Baraya Travel Bandung.
Analisis data dilakukan, yaitu: (1) Analisis sebelum pengumpulan data di lapangan. Peneliti melakukan penelaahan terhadap penelitian terdahulu yang berhubungan dengan penerapan BSC di perusahaan jasa, melakukan studi literatur mengenai pengukuran kinerja dan hambatan dalam melakukan pengukuran kinerja. (2) Analisis saat berada di lokasi penelitian dilakukan dengan pengembangan pertanyaan yang tidak terstruktur apabila dirasa jawaban yang diberikan oleh informan kurang memenuhi kebutuhan data.

Gambar 2 menunjukkan model perancangan penelitian untuk mengukur kinerja perusahaan di Baraya Travel Bandung.

\section{HASIL}

Pengukuran kinerja yang digunakan Baraya Travel Bandung saat ini adalah menggunakan laporan mingguan, melalui penilaian terhadap aspek pelayanan karyawan, ketersediaan peralatan kerja yang mendukung, kondisi objektif outlet, serta lebih menitikberatkan pada tingkat penjualan atau sales target. Pengukuran kinerja belum menggambarkan visi dan misi sebagai tujuan dan cita-cita perusahaan karena dalam melakukan pengukuran kinerjanya. Baraya Travel Bandung tidak menterjemahkan visi dan misi kedalam sasaran strategis dan tujuan yang ingin dicapai. Aspek dalam pengukuran kinerja perusahaan lebih menilai terhadap kondisi objektif outlets dan capaian terhadap target penjualan yang telah ditetapkan. Pengukuran kinerja outlet dilakukan oleh seorang Supervisor dibantu dengan Leader. Capaian kinerja kemudian dilaporkan Supervisor sebagai pemegang cabang Baraya Travel Bandung kepada Baraya Travel Jakarta. Gambar 3 merupakan mekanisme penilaian kinerja dengan melakukan pengisian data monitoring operator dan outlets yang diterapkan di Baraya Travel Bandung.

Sistem pengukuran kinerja yang digunakan oleh Baraya Travel Bandung adalah dengan menggunakan laporan mingguan (weekly report) dan indikator dari Standard Point Outlets, Standard Point Operator, dan Key Performance Indicator Outlets. Pengukuran kinerja Baraya Travel Bandung lebih menekankan kepada capaian target penjualan, sehingga kinerja Baraya Travel Bandung dikatakan baik apabila dapat mencapai target penjualan atau melebihi target penjualan. Indikator pengukuran dalam Standard Point Outlets meliputi beberapa aspek penilaian terhadap kondisi objektif outlet serta ketersediaan aspek penunjang pelayanan di outlet Baraya Travel Bandung. Berbeda dengan Standard Point Outlets, indikator pengukuran pada Standard Point Operator meliputi aspek penilaian terhadap karyawan Baraya Travel Bandung dilihat dalam bentuk penampilan fisik serta bentuk pelayanan yang diberikan kepada konsumen. Sedangkan indikator dalam Key Performance Indicator Outlets mengukur capaian target penjualan, kedisiplinan karyawan, 
kebersihan dan perawatan outlet serta peralatan promosi pendukung lainnya.

Siklus hidup bisnis dalam perspektif finansial Menurut Kaplan dan Norton (2000:42) terbagi menjadi tiga tahap yaitu bertumbuh (growth), bertahan (sustain) dan menuai (harvest). Melalui rancangan jangka panjang Baraya Travel Bandung yang mengacu pada Baraya Travel pusat, kondisi bisnis perusahaan ini dapat dikategorikan berada pada tahap bertumbuh (growth). Hal ini disebabkan Baraya Travel Bandung dalam menjalankan bisnisnya terus memberikan pengembangan produk baru, khususnya dalam pelayanan jasa transportasi dan pengiriman paket. Diterapkannya strategi pertumbuhan oleh perusahaan dan dipilihnya pertumbuhan profitabilitas melalui tingkat pendapatan penjualan dan tingkat efektivitas penggunaan aset yang dimiliki perusahaan menjadi sasaran strategis perusahaan berkaitan dengan perspektif keuangan.

Penjualan Baraya Travel Bandung hingga saat ini masih terus tumbuh, pada tahun 2017, namun baru mencapai angka $80 \%$ dari total target penjualan. Pendapatan penjualan Baraya Travel Bandung mengalami kenaikan dari tahun sebelumnya (Tabel 1).

Tabel 1 merupakan capaian dari pendapatan penjualan Baraya Travel Bandung selama tiga tahun. Pada tahun 2016 terjadi peningkatan yang tinggi karenan terjadi kerusakan jembatan Cisomang di tol Purbaleunyi sehingga tidak dapat dilalui oleh bus dan penumpang bus beralih ke travel.

ROA (Return On Assets) dapat dihitung melalui laba bersih sebelum pajak dibagi dengan total aset yang dimiliki perusahaan. Tabel 2 merupakan nilai ROA Baraya Travel Bandung tahun 2014 sampai dengan 2016

Berkaitan kondisi bisnis perusahaan yang dikategorikan tumbuh (growth), maka dengan perspektif pelanggan perusahaan memiliki potensi untuk berkembang dan menciptakan profitabilitas pelanggan melalui pencapaian penjualan yang diharapkan oleh perusahaan, serta mampu memberikan kepuasan bagi pelanggan melalui pelayanan yang terbaik. Hingga saat ini, Baraya Travel Bandung memiliki lebih dari 12.000 member dan belum termasuk pelanggan yang tidak terdaftar sebagai member.

Sasaran strategis yang ingin dicapai dalam perspektif pelanggan yaitu profitabilitas pelanggan melalui pencapaian berdasarkan penjualan yang diharapkan perusahaan serta kepuasan pelanggan yang mengukur sejauh mana pelanggan merasa terpuaskan atas pelayanan yang diberikan Baraya Travel Bandung.

Penentuan target penjualan mengacu kepada keputusan direktur dan manajer, sehingga target penjualan Baraya Travel Bandung mengikuti target penjualan yang telah ditetapkan oleh kantor pusat. Target penjualan Baraya Travel Bandung ditetapkan setiap tahunnya serta mengalami kenaikan pada setiap tahunnya. Berdasarkan hasil wawancara dengan manajer, rata-rata kenaikan target penjualan berada pada kisaran 5\% hingga 7\%.
Tabel 3 menunjukkan proyeksi target penjualan dan kuantitas penjualan hingga Agustus 2017, tren perbandingan target penjualan dan kuantitas penjualan mengalami fluktuasi, kuantitas penjualan terbesar terjadi pada bulan Juni dikarenakan terdapat hari besar yaitu hari raya Idul Fitri sehingga penjualan travel meningkat tajam sedangkan kuantitas penjualan terendah berada pada bulan Februari, tren target penjualan mengalami peningkatan rata-rata diatas 5\%, menurut Supervisor Baraya Travel Bandung, pencapaian target penjualan pada tahun 2017 baru mencapai pada angka $80 \%$.

Kepuasan pelanggan merupakan suatu keadaan dimana kebutuhan, keinginan dan harapan pelanggan dapat terpenuhi melalui produk atau pelayanan yang diberikan. Pendapatan yang diterima oleh perusahaan salah satunya adalah dari pelanggan itu sendiri sebagai pengguna jasa perusahaan, sehingga pentingnya perusahaan dalam memberikan perhatian penuh pada kepuasan pelangan. Kepuasan pelanggan dapat berdampak pada loyalitas pelanggan, sehingga mampu memberikan kontribusi terhadap kinerja keuangan perusahaan. Salah satu indikator kepuasan pelanggan adalah adanya pembelian atau pemakaian jasa secara berulang serta merekomendasikan perusahaan kepada orang lain.

Gambar 4 merupakan hasil survei yang dilakukan melalui wawancara mendalam terhadap tujuh informan yang tersebar di beberapa outlets Baraya Travel Bandung, lima orang diantaranya telah menggunakan Baraya Travel Bandung selama lebih dari 3 tahun. Mereka mengaku cukup puas selama menggunakan Baraya Travel Bandung, walaupun sesekali mereka mengalami kekecewaan dalam hal keterlambatan jadwal keberangkatan dan kondisi armada.

Proses bisnis internal yang dilakukan Baraya Travel Bandung meliputi proses inovasi dengan melakukan pengembangan produk yang sesuai dengan kebutuhan masyarakat, hingga saat ini Baraya Travel membuka layanan travel, pengiriman paket dan cargo, serta perjalanan wisata. Baraya Travel hingga saat ini memandang perkembangan teknologi sebagai peluang bagi perusahaan dalam memberikan pelayanan yang prima sehingga perusahaan mampu untuk terus mengembangkan proses pelayanan yang diberikan perusahaan bagi pelanggan, salah satunya adalah melalui pengembangan aplikasi Baraya Travel yang memungkinkan pelanggan melakukan booking tiket serta mampu mengakses informasi tentang Baraya Travel melalui aplikasi yang dapat diunduh oleh smartphone. Sistem pembelian dan booking tiket dapat dilakukan pula melalui website dan hotline yang tersedia sehingga perusahaan berusaha memberikan pelayanan yang memudahkan pelanggan. Sasaran strategis yang termasuk dalam perspektif proses bisnis internal adalah inovasi proses dan pengembangan produk sebagai upaya yang hingga saat ini terus dilakukan oleh perusahaan, serta kualitas pelayanan yang diberikan perusahaan 
guna memenuhi segala kebutuhan transportasi bagi pelanggan.

Pengembangan produk yang dilakukan oleh Baraya Travel Bandung adalah melalui beberapa pelayanan jasa lainnya yang memiliki bidang bisnis yang sama yaitu di bidang jasa transportasi. Pelayanan jasa yang dimiliki hingga saat ini adalah pelayanan transportasi travel Bandung - Jakarta, jasa pengiriman paket khusus untuk wilayah Bandung - Jakarta sedangkan untuk jasa pengiriman paket diluar wilayah Bandung - Jakarta, Baraya Travel memiliki jasa pengiriman melalui cargo yang dapat menjangkau seluruh wilayah di Indonesia dan layanan jasa yang terbaru adalah layanan perjalan wisata Baraya Tours \& Travel dengan sistem penyewaan bus untuk tujuan wisata tertentu atau penyewaan bus untuk antar jemput karyawan. Menurut Supervisor Baraya Travel Bandung layanan jasa travel dan pengiriman paket serta layanan Baraya Tours and Travel hingga saat ini masih terus tumbuh.

Baraya Travel Bandung memberikan perhatian penuh pada kualitas pelayanan dengan terus berupaya dalam meningkatkan kualitas pelayanan berupa peningkatan fasilitas outlet, kebersihan outlet, perawatan armada secara berkala, serta memberikan kemudahan bagi konsumen dalam melakukan transaksi atau booking ticket. Keseriusan Baraya Travel Bandung dalam upaya peningkatan pelayanan didukung pula oleh layanan keluhan konsumen yang dimiliki oleh Baraya Travel melalui SMS ke no hotline yang tersedia di outlet dan di dalam armada. Hingga saat ini, Baraya Travel sedang melakukan pemasangan GPS (Global Positioning System) terhadap seluruh armadanya, sehingga sistem dapat mendeteksi kecepatan laju armada yang dibatasi kecepatannya. Berikut ini merupakan survei yang dilakukan oleh peneliti melalui wawancara mendalam dengan pelanggan Baraya Travel Bandung yang tersebar di beberapa outlet.

Gambar 5 menunjukkan hasil survei kualitas pelayanan Baraya Travel Bandung melalui wawancara mendalam dengan pelanggan Baraya Travel Bandung di beberapa outlet Baraya Travel Bandung, hasil survei menunjukan 2 informan pria dan 1 informan wanita menyatakan puas dengan pelayanan yang diberikan serta 1 informan pria dan 3 informan wanita menyatakan cukup puas namun terdapat beberapa keluhan yang dirasakan yaitu keterlambatan jadwal, terkadang AC kurang berfungsi dengan baik, serta perawatan armada harus lebih ditingkatkan kembali agar mampu memberikan pelayanan yang prima dari segi armada yang digunakan.

Perspektif pembelajaran dan pertumbuhan merupakan pondasi bagi terciptanya hubungan sebab akibat dari perspektif lainnya dalam Balanced Scorecard, sehingga sumberdaya manusia merupakan faktor yang sangat penting bagi perusahaan untuk tumbuh dan berkembang. Dengan demikian Baraya Travel Bandung membutuhkan karyawan yang dapat melaksanakan fungsi kerja dengan bik dalam menciptakan profitabilitas perusahaan. Tujuan dari sasaran strategis yang ditetapkan meliputi kompetensi rata-rata yang dimiliki karyawan sehingga berperan untuk menunjang hasil kerja yang diharapkan bagi perusahaan serta produktivitas karyawan yang merupakan bagian dari kapabilitas pekerja sebagai bagian dari ukuran inti perspektif pembelajaran dan pertumbuhan.

Berdasarkan hasil wawancara dengan supervisor Baraya Travel Bandung dan manajer Baraya Travel, hingga saat ini Baraya Travel Bandung memiliki karyawan yang berpendidikan SMA sebesar $80 \%$ dan sisanya berpendidikan Diploma 10\% dan Sarjana 10\%. Karyawan dengan berpendidikan SMA mengisi posisi jabatan sebagai operator tiket yang memiliki kemampuan dalam mengoperasikan komputer, microsoft word dan microsoft excel serta memiliki sopan santun yang baik dalam melayani konsumen. Sedangkan untuk jenjang pendidikan SMP diisi sebagai supir Baraya Travel Bandung dengan memiliki keahlian dalam mengemudikan armada elf dan ditunjukan melalui kepemilikan SIM B1 umum. Berikut ini merupakan diagram kompetensi karyawan dilihat dari aspek pendidikan.

Gambar 6 menunjukkan persentase kompetensi rata-rata karyawan Baraya Travel Bandung, karyawan Baraya Travel Bandung didominasi oleh lulusan SMA sebesar $80 \%$ yaitu berjumlah 168 orang, sedangkan lulusan Diploma dan Sarjana masing-masing sebesar $10 \%$ yaitu berjumlah 21 orang, lulusan SMA menempati jabatan sebagai operator tiket dan supir sedangkan untuk lulusan Diploma dan Sarjana menempati posisi sebagai Leader, Supervisor, dan Manajer.

Produktivitas memiliki tujuan untuk menghubungkan output yang dihasilkan karyawan dengan jumlah karyawan yang digunakan untuk menghasilkan output tersebut. Produktivitas mengarah kepada pencapaian kerja yang maksimal dan berkaitan dengan kualitas, kuantitas dan waktu, serta produktivitas mengarah pada efisiensi yang berkaitan dengan ipaya membandingkan input dengan realisasi penggunaannya atau bagaimana pekerjaan tersebut dilaksanakan. Ukuran yang digunakan yaitu rasio produktivitas karyawan dengan membandingkan volume layanan Baraya Travel dengan jumlah karyawan. Berdasarkan hasil wawancara mendalam dengan manajer Baraya Travel, jumlah karyawan Baraya Travel Bandung pada tahun 2014 berjumlah 158 orang, terjadi peningkatan jumlah karyawan pada tahun 2015 menjadi 179 dan pada tahun 2016 terjadi peningkatan kembali menjadi 210 orang, kenaikan jumlah karyawan didasarkan pada kebutuhan pengemudi armada.

Tabel 4 menunjukkan rasio produktivitas karyawan Baraya Travel Bandung melalui perbandingan volume layanan sebagai output dan jumlah karyawan sebagai input, berdasarkan tabel diatas, produktivitas karyawan Baraya Travel Bandung mengalami fluktuasi, hal tersebut 
disebabkan karena kurang optimalnya perbandingan antara penambahan karyawan dengan tingkat kenaikan volume layanan. Pengukuran kinerja Baraya Travel Bandung lebih menekankan pada pencapaian target penjualan dan keuntungan saja, hal tersebut karena perusahaan berorientasi pada keuntungan.

Hambatan yang sering muncul dalam melakukan pengukuran kinerja adalah indikator capaian hasil yang digunakan yaitu hanya dengan capaian target penjualan, sedangkan capaian target penjualan merupakan data historis dan data masa lalu yang tidak mampu menggambarkan kondisi di masa yang akan datang, sehingga Baraya Travel Bandung masih berorientasi jangka pendek.

Hasil yang didasarkan pada orientasi jangka pendek memungkinkan perusahaan untuk sulit berkembang karena hanya menggunakan data masa lalu sebagai acuan kinerjanya, sehingga akan berimplikasi terhadap operasional perusahaan yang sulit untuk berkembang karena masih minimnya ukuran-ukuran hasil yang menggambarkan orientasi dalam jangka panjang perusahaan, hal tersebut senada dengan Niven dalam Kartika dan Ardianto (2013). Hambatan lainnya adalah mengenai subjektifitas penilaian yang dilakukan oleh leader karena penilaian berdasarkan pengamatan setiap leader sehingga memungkinkan terjadinya bias dalam penilaiannya serta klasifikasi penilaiannya hanya berdasarkan pada nilai mutu dan poin tertentu.

\section{PEMBAHASAN}

Tahapan pertama yang dilakukan dalam melakukan perancangan sistem pengukuran kinerja berbasis Balanced Scorecard adalah dengan menentukan arsitektur pengukuran melalui visi, misi perusahaan serta strategi korporasi perusahaan. Visi, misi dan strategi korporasi tersebut dijadikan sebagai arsitektur pengukuran kinerja perusahaan karena pada dasarnya sistem pengukuran kinerja berbasis Balanced Scorecard berawal dari visi, misi dan strategi korporasi perusahaan yang menjadi dasar dan tujuan-tujuan yang ingin dicapai oleh perusahaan.

Berdasarkan misi dapat ditentukan strategi korporasi serta tujuan strategis yang ingin dicapai oleh perusahaan, meliputi: (1) Meningkatkan pendapatan melalui penjualan dan penggunaan asset, (2) Meningkatkan kualitas pelayanan melalui berbagai inovasi pelayanan dengan penguasaan teknologi, (3) Memastikan pelanggan merasa puas dengan memberikan kenyamanan dan keamanan, (4) Memperluas lini usaha dengan mengembangkan produk dalam bidang jasa transportasi, (5) Memberikan jenjang karir bagi karyawan yang memiliki kompetensi dalam upaya mempersiapkan sumberdaya manusia yang unggul

Penetapan tujuan diturunkan melalui penjabaran visi, misi dan strategi Baraya Travel Bandung ke dalam perspektif BSC dan strategi korporasi sehingga diketahui tujuan-tujuan strategis yang diharapkan oleh Baraya Travel Bandung. Pembobotan keempat perspektif dilakukan berdasarkan perspektif BSC, hal tersebut dilakukan untuk mengetahui bahwa perusahaan lebih menitikberatkan pada salah satu perspektif BSC.

Tabel 5 merupakan pembobotan terhadap empat perspektif BSC yang didasarkan pada hasil wawancara mendalam dengan eksekutif perusahaan, dapat diketahui bahwa perusahaan menitikberatkan pada pencapaian berdasarkan perspektif finansial yang berkaitan dengan pendapatan perusahaan, dan diikuti oleh perspektif pelanggan dalam memberikan kualitas pelayanan yang baik dan kepuasan bagi pelanggan, perspektif proses bisnis internal dan perspektif pembelajaran dan pertumbuhan.

Sasaran strategis dalam setiap perspektif BSC merupakan perwujudan strategi yang berhubungan satu sama lain. Hubungan sebab akibat yang terlihat pada setiap sasaran strategis menunjukkan koherensi setiap tindakan. Koherensi berarti bahwa suatu pencapaian sasaran strategis tertentu akan berdampak pada pencapaian sasaran strategi lainnya.

Ukuran kinerja yang digunakan yaitu dengan menggunakan key performance indicator (KPI)sebagai indikator kunci kinerja yang terbagi kedalam lagging indicators sebagai indikator hasil (outcome) dan dapat mengukur hasil dari aktivitas yang sudah dilakukan Baraya Travel Bandung dalam mencapai tujuannya, indikator kunci kinerja lainnya dari KPI yaitu leading indicators yang merupakanindikator penggerak (driver) dan merupakan kinerja yang diharapkan oleh Baraya Travel Bandung untuk mencapai hasil akhir yang diharapkan.

Terdapat dua tujuan strategis berdasarkan perspektif finansial yaitu kemampuan perusahaan dalam memperoleh laba melalui hasil penjualan, sehingga yang menjadi lag indicators adalah pendapatan penjualan perusahaan dan tujuan strategis yang kedua adalah kemampuan perusahaan dalam memperoleh laba melalui aset yang dimiliki sebagai lag indicators. Sedangkan berdasarkan perspektif pelanggan, terdapat dua lag indicators yang didasarkan pada tujuan strategis perusahaan yaitu pencapaian dari target penjualan dengan persentase capaian penjualan sebagai lag indicators dan kepuasan pelanggan yang tinggi dengan tingkat kepuasan pelanggan yang menjadi lag indicators. Melalui perspektif proses bisnis internal, Baraya Travel memiliki tujuan strategis diantaranya memiliki kualitas pelayanan yang baik dan tingkat kualitas pelayanan sebagai lag indicators. Tujuan strategis lainnya berdasarkan perspektif proses bisnis internal adalah dengan meningkatkan sistem kerja dan pelayanan yang lebih efektif melalui pemanfaatan teknologi dengan lag indicators tingkat persentase sistem kerja dan pelayanan berbasis teknologi, serta tujuan strategis lainnya yaitu pengembangan produk baru yang bergerak di bidang jasa transportasi dengan jumlah 
produk baru yang dihasilkan sebagai lag indicators. Melalui perspektif pembelajaran dan pertumbuhan, tujuan strategis perusahaan meliputi kompetensi yang dimiliki karyawan dengan tingkat kompetensi karyawan sebagai lag indicators dan produktivitas karyawan dengan tingkat produktivitas karyawan sebagai lag indicators.

Berdasarkan perspektif finansial beserta lag indicators yang telah dirumuskan, terdapat beberapa indikator hasil yaitu pendapatan penjualan yang dapat diukur melalui tingkat penjualan, sehingga tingkat penjualan dianggap sebagai indikator penggerak dari pendapatan penjualan, sedangkan indikator penggerak bagi pengembalian aset adalah tingkat pengembalian aset itu sendiri. Berdasarkan perspektif pelanggan, terdapat dua indikator hasil yaitu persentase capaian penjualan dengan tingkat capaian penjualan sebagai indikator penggerak dan tingkat kepuasan pelanggan dengan rancangan survei wawancara sebagai indikator penggerak yang artinya untuk mengetahui tingkat kepuasan pelanggan salah satunya dapat dilakukan melalui survei. Sedangkan untuk perspektif proses bisnis internal, terdapat tiga indikator hasil yaitu tingkat kualitas pelayanan yang dapat diketahui melalui indikator penggerak yaitu survei pada pelanggan, indikator hasil yang kedua adalah persentase sistem kerja dan pelayanan berbasis teknologi dengan sistem kerja baru, proses pelayanan baru dan penguasaan teknologi sebagai indikator penggeraknya (lead indicators), indikator hasil yang ketiga adalah jumlah produk baru yang dihasilkan dengan perancangan produk baru sebagai indikator penggeraknya. Berdasarkan perspektif pembelajaran dan pertumbuhan, terdapat dua indikator hasil yaitu tingkat kompetensi karyawan dengan mengukur kompetensi rata-rata karyawan sebagai indikator penggeraknya, serta indikator hasil untuk mengetahui tingkat produktivitas karyawan dengan mengetahui jumlah karyawan dan pendapatan perusahaan sebagai indikator penggeraknya.

Penetapan target merupakan tahap yang dilakukan untuk menentukan capaian yang diharapkan oleh Baraya Travel Bandung.Peneliti tidak mendapatkan akses untuk merumuskan capaian yang diharapkan bersama dengan para pengambil keputusan, sehingga penelitian ini dibatasi hingga formulasi yang didasarkan pada KPI.

Berdasarkan ukuran dari sasaran strategis Baraya Travel Bandung melalui KPI, didapatkan bahwa lag indicators berdasarkan perspektif finansial adalah pendapatan penjualan (sales revenue) dan tingkat pengembalian aset perusahaan.Baraya Travel Bandung senantiasa memberi perhatian tinggi pada upaya untuk memuaskan pelanggannya melalui berbagai peningkatan pelayanan dan peningkatan kualitas jasa. Sasaransasaran strategis Baraya Travel Bandung berdasarkan perspektif pelanggan mengarah kepuasan pelanggan dan capaian target penjualan. Berdasarkan ukuran kinerja $\mathrm{KPI}$, lag indicators untuk perspektif pelanggan meliputi persentase capaian penjualan dan tingkat kepuasan pelanggan.

Sasaran strategis Baraya Travel Bandung berdasarkan perspektif proses bisnis internal mengarah kepada peningkatan sistem kerja yang lebih baik melalui pemanfaatan teknologi yang dipandang sebagai inovasi proses. Berdasarkan ukuran kinerja melalui KPI, terdapat tiga indikator hasil yang menjadi sasaran bagi Baraya Travel Bandung berdasarkan perspektif proses bisnis internal, yaitu tingkat kualitas pelayanan, persentase inovasi sistem kerja dan pelayanan berbasis teknologi dan pengembangan produk baru di bidang jasa transportasi.

Berdasarkan ukuran kinerja dari sasaran-sasarn strategis Baraya Travel Bandung pada perspektif pembelajaran dan pertumbuhan, terdapat dua indikator hasil (lag indicators) yang dapat dijadikan sebagai tolak ukur pencapaian sasaran strategis perusahaan. Baraya Travel Bandung menekankan perhatian kepada tingkat kompetensi yang dimiliki karyawan serta produktivitas karyawan.

\section{KESIMPULAN}

Model pengukuran kinerja yang digunakan Baraya Travel Bandung masih menerapkan sistem yang menitikberatkan pada pencapaian target penjualan, kondisi outlet,dan pelaksanaan SOP karyawan. Pengukuran melalui laporan mingguan tentang kondisi outlet meliputi penilaian terhadap standard point operator, standard point outlets dan key performance indicators outlet. Implementasi pengukuran kinerja Baraya Travel Bandung kurang optimal, karena fokus pada pelayanan dan target penjualan.

Capaian target penjualan Baraya Travel Bandung masih terus tumbuh hingga Agustus 2017 rata-rata 5\% hingga $7 \%$. Pencapaian target penjualan pada tahun 2017 masih dalam angka 80\% dari target penjualan yang telah ditetapkan. Upaya dalam peningkatan pelayanan pada tahun 2014 yang telah menggunakan sistem online dan melalui komputerisasi, hingga tahun 2017, Baraya Travel telah mengembangkan aplikasi yang mampu memberikan berbagai kemudahan bagi pelanggan.

Hambatan yang dirasakan adalah seringnya terjadi kendala informasi dan komunikasi serta penanggulangan dari berbagai tindakan perbaikan yang diajukan kepada Baraya Travel pusat. Tolok ukur penilaian kinerja perusahaan yang hanya menggunakan aspek keuangan merupakan salah satu hambatan bagi penilaian kinerja perusahaan, karena perusahaan akan sulit untuk berkembang dan memiliki eksistensi dalam jangka panjang. Ketidakjelasan alat ukur kinerja dan ketidakterukuran penilaian kinerja merupakan salah satu hambatan dalam melakukan pengukuran kinerja di Baraya Travel Bandung. Alat ukur kinerja belum mengukur keseluruhan aktivitas bisnis dari empat fungsional manajemen. 
Langkah perancangan alat ukur kinerja berbasis BSC di Baraya Travel Bandung diawali dengan penentuan arsitektur pengukuran melalui visi, misi, sasaran dan tujuan strategis.Kemudian dilakukan penetapan tujuan dengan melakukan pembobotan terhadap empat perspektif BSC. Penetapan ukuran kinerja dilakukan dengan menggunakan KPI meliputi lag indicators dan lead indicators. Penetapan target dibatasi hingga formulasi dari KPI. Rancangan BSC memungkinkan perumusan KPI yaitu pendapatan penjualan, ROA, persentase capaian penjualan, survei kepuasan pelanggan, survei kualitas pelayanan, persentase sistem kerja dan pelayanan berbasis teknologi, total jumlah produk baru pada periode tertentu, survei kompetensi rata-rata karyawan dan tingkat produktivitas karyawan melalui perbandingan volume layanan dan jumlah karyawan.

\section{DAFTAR PUSTAKA}

Alao, E., 2013. Strategic Decision Making, Balanced Scorecard Profitability: Issues and Challenges. International Journal of Accounting Research, 42(826), pp.1-12.

Awadallah, E.A. and Allam, A., 2015. A critique of the balanced scorecard as a performance measurement tool. International Journal of Business and Social Science, 6(7), pp.91-99.

Brillianty, S.F. and Bendatu, L.Y., 2013. Perancangan Alat Ukur Penilaian Kinerja di PT X dengan Menggunakan Balanced Scorecard. Jurnal Titra, 1(2), pp.149-156.

Divandri, A. and Yousefi, H., 2011. Balanced Scorecard: A Tool for Measuring Competitive Advantage of Ports with Focus on Container Terminals. International Journal of Trade, Economics and Finance, 2(6), p.472.

Farooq, A. and Hussain, Z., 2011. Balanced scorecard perspective on change and performance: a study of selected Indian companies. Procedia-Social and Behavioral Sciences, 24, pp.754-768.

Fill, M., Buša, M. and Puškáś, E., 2015. Measurement of Business Performance Using The Method Balanced Scorecard. The International Journal of Transport \& Logistics. Vol. 15, No. 34-36, pp. 1-8.

Huatuco, L.D.H., Montoya-Torres, J.R., Shaw, N., Calinescu, A., Reefke, H. and Trocchi, M., 2013. Balanced scorecard for sustainable supply chains: design and development guidelines. International Journal of Productivity and Performance Management.
Kaplan, Robert S. 2010. Conceptual Foundations of The Balanced Scorecard. Working Paper. 10-074. Harvard Business School. Harvard University.

Kairu, Wafula., Okaka, Odera \& Akrele. 2013. Effects of Balanced Scorecard on Performance of Firms in the Service Sector. European Journal of Business and Management. Vol. 5 No. 9.

Kartika, T. and Ardianto, J., 2013. Perancangan Metode Balanced Scorecard Pada PT Samchem Prasandha. JMA, 18(2), pp.62-89..

Malgwi, A. A \& Dahiru, H. 2014. Balanced Scorecard Financial Measurement of Organizational Performance: A Review. IOSR Journal of Economics and Finance (IOSR-JEF). Vol. 4 Issue 6. July-Aug. PP $01-10$.

Maslihatin, Tatik. 2016. Balanced Scorecard : Performance Measurement for E-Government. Journal of Theoretical and Applied Information Technology. Vol. 90, No.2, pp. 116-123.

Quesado, P.R., Aibar Guzmán, B. and Lima Rodrigues, L., 2018. Advantages and contributions in the balanced scorecard implementation. Intangible capital, 14(1), pp.186-201.

Rajnoha, R. and Lesníková, P., 2016. Strategic performance management system and corporate sustainability concept-specific parametres in Slovak Enterprises. Journal of Competitiveness, 8(3).

Ridwan, R., Harun, H., An, Y. and Fahmid, I.M., 2013. The impact of the balanced scorecard on corporate performance: The case of an Australian public sector enterprise. International Business Research, 6(10), p. 103.

Saad, R. and Daraghma, Z., 2016. Using of the Balanced Scorecard for Performance Evaluation: Empirical Evidence from the Listed Corporations in the Palestine Exchange (PEX). International Journal of Business and Management, 11(3), pp.215-222.

Senvar, M.O., Vayvay, O., Kurt, E. and Hloch, S., 2014. Prioritization of balanced scorecard measurement indicators as a process management approach via fuzzy AHP: case study in automotive industry. Tehnički vjesnik, 21(1), pp.155-162.

Zhijun, L.I.N., Zengbiao, Y.U. and Zhang, L., 2014. Performance outcomes of balanced scorecard application in hospital administration in China. China Economic Review, 30, pp.1-15.

Zizlavsky, O., 2014. The balanced scorecard: Innovative performance measurement and management control system. Journal of technology management \& innovation, 9(3), pp.210-222. 


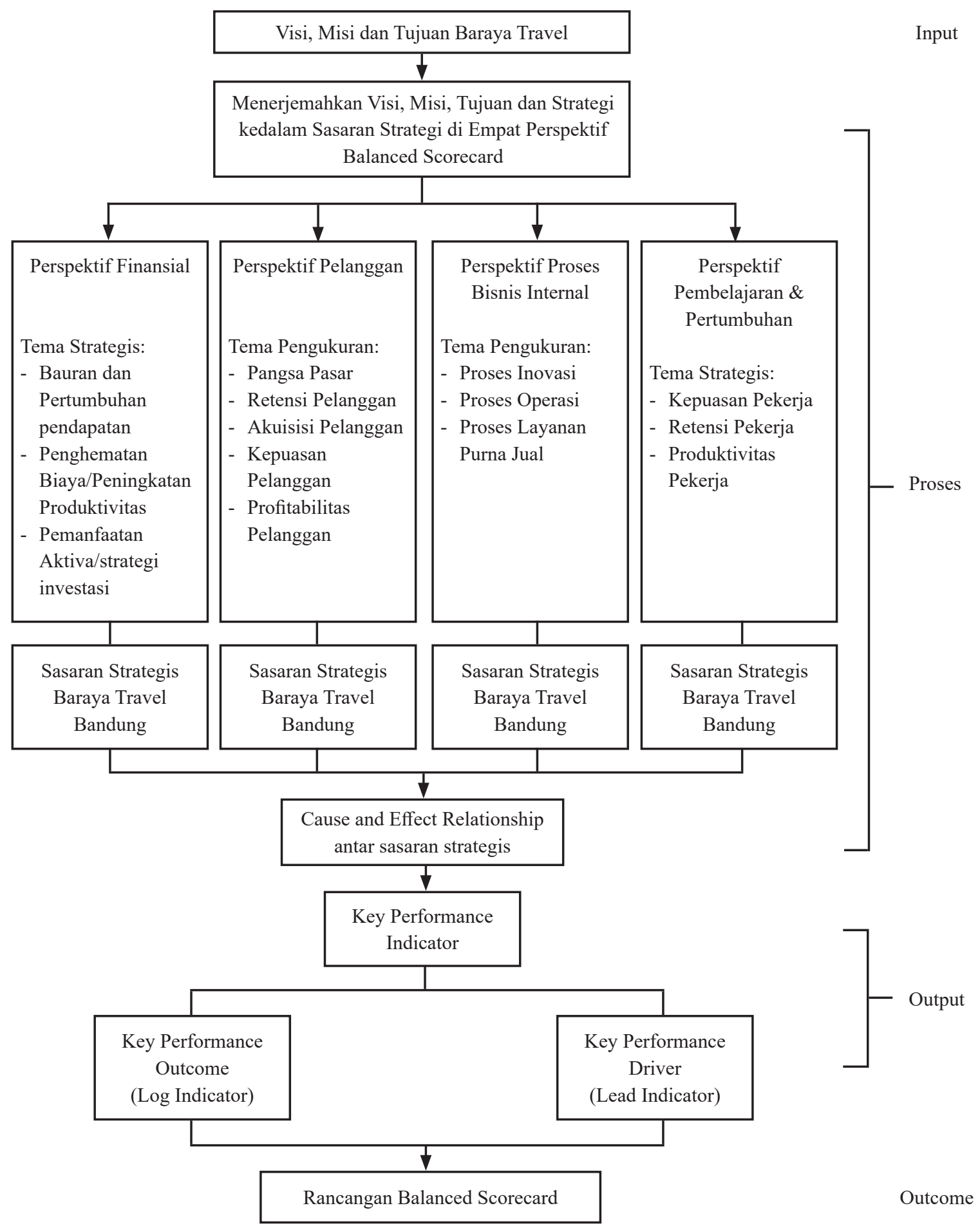

Gambar 1. Kerangka Pemikiran 


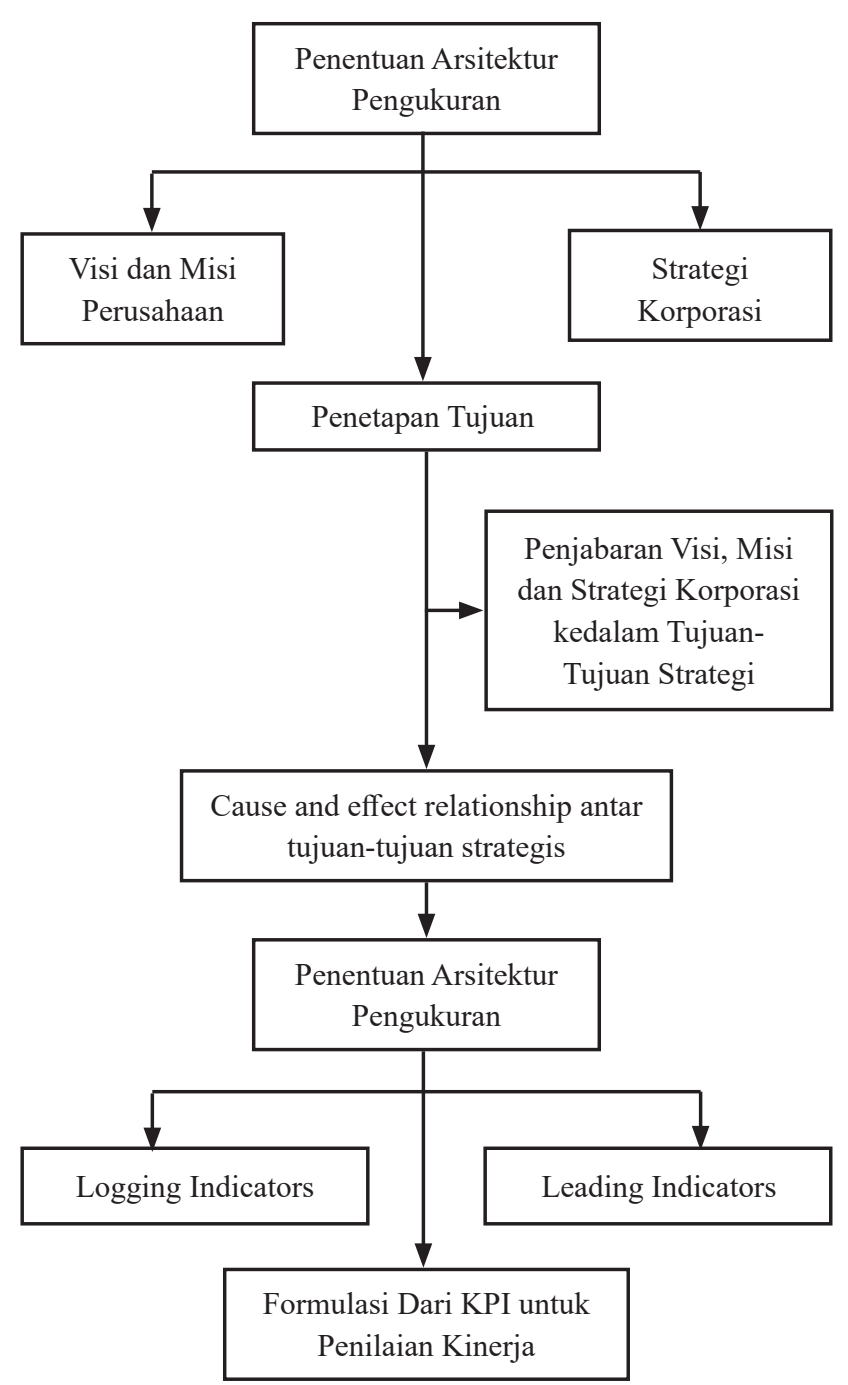

Gambar 2. Model Perancangan Penelitian

\begin{tabular}{|c|c|c|}
$\begin{array}{c}\text { Kunjungan ke } \\
\text { Outlet secara } \\
\text { Berkala } \\
(1 \mathrm{minggu} / 2 \\
\text { minggu })\end{array}$ & $\rightarrow$ & $\begin{array}{c}\text { Penilaian } \\
\text { Berdasarkan } \\
\text { Kejadian } \\
\text { Langsung dan } \\
\text { Secara Objektif }\end{array}$
\end{tabular}$\longrightarrow \begin{gathered}\text { Hasil Penilaian } \\
\text { Didiskusikan } \\
\text { setiap Weekly } \\
\text { Meeting } \\
\text { Manager }\end{gathered}$

Sumber : Hasil wawancara mendalam dengan Supervisor

Gambar 3. Mekanisme Penilaian Kinerja Baraya Travel Bandung

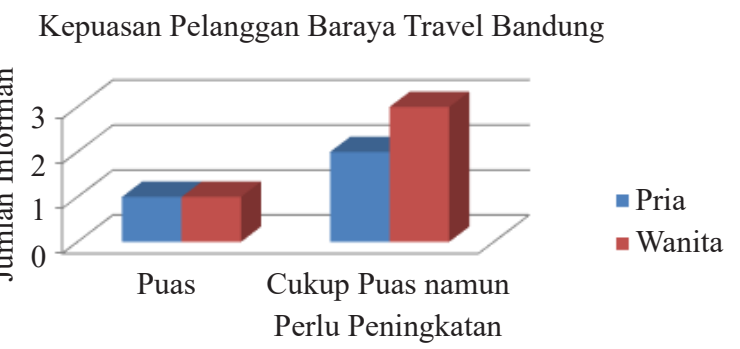

Klasifikasi

Sumber : Diolah oleh peneliti dari hasil wawancara mendalam

Gambar 4. Hasil Survei Kepuasan Pelanggan Baraya Travel Bandung
Kepuasan Pelanggan Baraya Travel Bandung

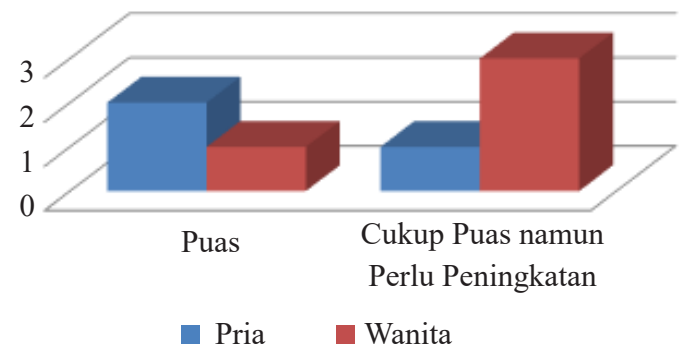

Sumber : Diolah oleh peneliti dari hasil wawancara mendalam Gambar 5. Hasil Survei Kualitas Pelayanan Baraya Travel Bandung Kompetensi Rata-Rata Karyawan

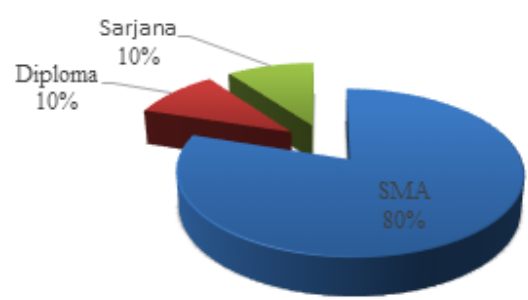

Gambar 6. Kompetensi Rata-Rata Karyawan Baraya Travel Bandung

Tabel 1. Sales Revenue Baraya Travel Bandung

\begin{tabular}{ccr}
\hline Tahun & Total Penjualan & \multicolumn{1}{c}{ Sales Revenue } \\
\hline 2014 & 107.854 & Rp. 8.763.556.000 \\
2015 & 119.465 & Rp. 9.718.706.000 \\
2016 & 139.529 & Rp. 11.486 .858 .000 \\
\hline
\end{tabular}

Sumber : Diolah oleh peneliti dari hasil wawancara dan dokumentasi

Tabel 3. Proyeksi Target Penjualan dan Kuantitas Penjualan Hingga Agustus 2017

\begin{tabular}{clcc}
\hline No. & Bulan & Target Penjualan & Kuantitas Penjualan \\
\hline 1. & Januari & 9.500 & 10.268 \\
2. & Februari & 11.295 & 9.853 \\
3. & Maret & 11.400 & 10.457 \\
4. & April & 11.700 & 10.967 \\
5. & Mei & 12.000 & 11.192 \\
6. & Juni & 12.840 & 13.698 \\
7. & Juli & 13.482 & 10.344 \\
8. & Agustus & 14.157 & 12.587 \\
\hline \multicolumn{3}{c}{ Total } \\
\hline
\end{tabular}

Sumber : Data diolah oleh peneliti

Tabel 5. Pembobotan Empat Perspektif Balanced Scorecard

\begin{tabular}{clc}
\hline No & \multicolumn{1}{c}{ Perspektif Balanced Scorecard } & Pembobotan \\
\hline 1 & Finansial & 0,4 \\
2 & Pelanggan & 0,3 \\
3 & Proses Bisnis Internal & 0,2 \\
4 & Pembelajaran \& Pertumbuhan & 0,1 \\
\hline & Total Pembobotan & 1,00 \\
\hline
\end{tabular}

Sumber : Diolah oleh peneliti dari hasil wawancara mendalam 
Tabel 2. ROA Baraya Travel Bandung

\begin{tabular}{clll}
\hline Return On Assets (ROA) & \multicolumn{2}{c}{2014} & \multicolumn{2}{c}{2015} & \multicolumn{1}{c}{2016} \\
\hline \multirow{2}{*}{ Laba Sebelum Pajak } & $=\frac{\text { Rp. } 473.832 .193}{\text { Rp. } 28.349 .854 .000}$ & $=\frac{\text { Rp. } 563.576 .435}{\text { Rp.29.624.721.000 }}$ & $=\frac{\text { Rp. 747.232.765 }}{\text { Rp. 29.956.256.000 }}$ \\
Total Pajak & $=0,016$ & $=0,019$ & $=0,024$ \\
\hline
\end{tabular}

Sumber : Diolah oleh peneliti dari hasil wawancara dan dokumentasi

Tabel 4. Rasio Produktivitas Karyawan Baraya Travel Bandung

\begin{tabular}{llcc}
\hline Rasio Produktivitas Karyawan & 2014 & 2015 & 2016 \\
\hline Volume Layanan (output) & $=\frac{\text { Rp. 8.763.556.000 }}{158 \text { orang }}$ & $=\frac{\text { Rp. 9.718.706.000 }}{179 \text { orang }}$ & $=\frac{\text { Rp. } 11.486 .858 .000}{210 \text { orang }}$ \\
Jumlah Karyawan (input) & $=$ Rp. 55.465.544,3/orang & $=$ Rp. 54.294.446,9/orang & $=$ Rp. 54.699.323,8/orang \\
\hline
\end{tabular}

Sumber : Diolah oleh peneliti dari hasil wawancara dan dokumentasi 